\title{
Sisteme ortografice și identitate lingvistică la comunitatea românofonă din estul Serbiei
}

\author{
Monica Huțanu ${ }^{1,2 *}$, Annemarie Sorescu-Marinković ${ }^{3 *}$ \\ ${ }^{1}$ Facultatea de Litere, Istorie și Teologie, Universitatea de Vest, Bd. Vasile Pârvan 4, 300223 Timişoara, România \\ ${ }^{2}$ Facultatea de Filologie, Universitatea din Belgrad, Studentski Trg 3, 11000 Belgrad, Serbia \\ ${ }^{3}$ Institutul de Studii Balcanice, Academia Sîrbă de Științe și Arte, Knez Mihailova 35/IV, 11000 Belgrad, Serbia
}

\section{Despre articol \\ Istoric:}

Primit 29 august 2017

Acceptat 2 octombrie 2017

Publicat 30 noiembrie 2017

Cuvinte-cheie:

sociolingvistică

comunități românofone

ortografie

\begin{abstract}
Rezumat
În studiul de față ne ocupăm dintr-o perspectivă preponderent sociolingvistică de sistemele de scriere create de-a lungul timpului pentru reprezentarea grafică a variantei limbii române vorbite de comunitatea românofonă din Serbia de est. Urmărim în special ce influențează alegerea unui alfabet (latin sau chirilic), a unor convenții ortografice și a unui sistem de scriere și cum se corelează această alegere cu atitudinea ideologică (reintegraționistă sau independentistă) a propunătorilor. În acest scop, analizăm sistemele ortografice utilizate pentru redarea vernacularei în „Vorba noastră”, prima publicație în varianta locală (1945-1948), și mai ales sistemele propuse în ultimii 20 de ani de membrii comunității angajați în dispute politice și lingvistice (Paun Es Durlić, Dragomir Dragić, Slavoljub Gacović, Ljubiša lu Boža Kići, Societatea „Gergina”). Analiza și compararea sistemelor demonstrează importanța factorilor ideologici, sociali și politici în crearea și impunerea unei ortografii pentru un idiom nescris.
\end{abstract}

\section{Preliminarii}

Crearea, impunerea sau reformarea unui sistem de scriere și a unei ortografii pentru un idiom nu sînt niciodată o întreprindere neutră, aseptică și lipsită de conflicte. Pentru limba română, mărturie stau, de exemplu, multiplele și variatele controverse privind introducerea scrierii cu alfabet latin în secolele XVIIIXIX sau nesfîrșitele polemici şi revolte create de reintroducerea grafemului <â în 1993. Definirea ortografiei ca simplă convenție se dovedește astfel insuficientă; un anume sistem de scriere nu doar reprezintă grafic elementele vorbirii sau servește la decodarea unui mesaj scris, ci e întotdeauna încărcat ideologic.

Ideologia (sau, mai frecvent, ideologiile concurente) din spatele alegerii unui anumit sistem de scriere sînt cu atît mai evidente în cazul elaborării unei ortografii pentru un idiom încă nescris. Alegerea pe care o face o comunitate cu privire la modul în care își va reprezenta vizual limba e și o decizie asupra felului în care îşi va reprezenta identitatea (Unseth, 2008, p. 1), nu doar în interiorul comunităţii, ci și la nivel național sau internațional. Analizînd sistemele ortografice propuse pentru redarea grafică a vernacularei folosite în Haiti (kreyòl), Schieffelin \& Doucet (1994) observă că, departe de a fi întemeiate pe o investigare strict științifică a faptelor lingvistice, ele sînt produse culturale care (re)prezintă diferit identitatea haitiană postcolonială (mai aproape sau mai departe de cea franceză), în funcție de anumite interese sociale și politice ale taberelor şi ideologiilor concurente. De altfel, prioritatea factorilor sociali, politici sau religioși asupra celor pur lingvistici, funcționali e bine documentată în cazul unor sisteme grafice create de și pentru diverse comunități și idiomuri, precum Hmong (Eira, 1998), Selsq (Priestly, 1992), Guernesiais (Sallabank, 2002). Printr-un proces de iconizare (Irvine \& Gal, 2000; Sebba, 2015), de transformare a relației convenționale într-una simbolică, sistemele grafice devin expresia identității unei comunități (Unseth, 2005, p. 20), embleme (Coulmas, 2009, p. 15) sau simboluri ale identității (Eira, 1998, p. 172), avînd nu doar semnificație lingvistică, ci și (mai ales) socială.

*Adrese de corespondență: monica.hutanu@e-uvt.ro(MH), annemariesorescu@gmail.com (ASM). 
Monica Huțanu, Annemarie Sorescu-Marinković

Ne propunem în cele ce urmează să analizăm dintr-o perspectivă preponderent sociolingvistică sistemele de scriere elaborate de-a lungul timpului pentru redarea graiului românofonilor din estul Serbiei, o variantă arhaică a limbii române, aflată mai bine de un secol în afara spaţiului de influență a românei standard. Intenția noastră nu e de a evalua validitatea acestor propuneri ortografice sau de a face judecăți de valoare, ci de a urmări ce influențează alegerea unui anumit sistem de scriere, cum sînt justificate alegerile ortografice și cum se corelează preferința pentru o anumită reprezentare grafică a acestei variante a românei cu poziția ideologică a propunătorilor.

\section{Comunitatea românofonă din estul Serbiei. Particularități lingvistice și socio- lingvistice}

La sud de Dunăre, pe teritoriul Serbiei, de-a lungul văilor rîurilor Timoc, Mlava, Morava și Pek, trăiește o comunitate preponderent rurală, în general bilingvă, cu o identitate multiplă, care folosește o variantă arhaică a limbii române, alături de limba oficială a statului, sîrba. Istoria comunităţii pornește, conform majorității cercetătorilor, în secolele XVIII-XIX, prin migrații dinspre Țara Românească și Banat (Constante, 1929; Meteș, 1971; Weigand, 1900). Migraţii de amploare au fost înregistrate în special în perioada 1718-1739, care a urmat războiului dintre Imperiul Austriac și cel Otoman, în care Serbia răsăriteană s-a aflat în componența districtului de Timișoara, administrat de contele Mercy. După această dată, migrațiile au continuat, avînd însă o intensitate redusă şi un caracter spontan. Persistența unei populații autohtone, propusă de unii cercetători (de ex. Popovici, 1919) și susţinută și de unii membri ai comunității, rămîne o ipoteză greu de demonstrat și care nu exclude oricum teoria migrațiilor succesive.

Identitatea scindată, între loialitatea față de statul sîrb și ,instinctul etnic” (Vâlsan, 1913, p. 343), rezultă și din datele celui mai recent recensămînt (2011), conform căruia comunitatea numără astăzi 35330 de membri de etnie vlahă, dar, în acelaşi timp, 43095 de respondenți care declară vlaha ca limbă maternă (cu alte cuvinte, peste 7000 de persoane s-au declarat (probabil) sîrbi avînd vlaha drept limbă maternă). Etnonimele folosite de membrii comunităţii reflectă și ele această identitate dublă: rumîn, cînd folosesc limba maternă, vlah, cînd vorbesc limba sîrbă. Termenul utilizat în vernaculară, rumîn, este concurat astăzi însă de termenul vlah, cu varianta vla (feminin vlaina), unii membri ai comunităţii apropriindu-și astfel exonimul, denumirea dată „din afară”, și respingînd explicit orice apropiere de identitatea românească. De aceea, din dorinţa de a nu părea că excludem o anumită parte a acestei comunități, preferăm termenul mai neutru și mai cuprinzător comunitate românofonă (Sorescu-Marinković, 2007; Sikimić, 2014; Florea, 2015), și nu pe cel încetățenit în literatura românească de specialitate și în discursul românesc, românii din Valea Timocului sau românii timoceni ${ }^{1}$.

Din punct de vedere lingvistic, graiul folosit de comunitatea românofonă din estul Serbiei poate fi considerat o variantă arhaică, neunitară, a limbii române, alcătuită din patru grupuri dialectale: țăranii, ungurenii, muntenii și bufanii. Deja primii cercetători ai comunității și ai limbii vorbite de ea au observat că graiul țăranilor este strîns legat de subdialectul muntean al românei, iar cel al ungurenilor de subdialectul bănățean (Constante, 1929; Pătruț, 1942; Petrovici, 1942). La aceste două grupuri principale, cercetările mai recente îi adaugă pe munteni (Durlić, 2011), care vorbesc un grai de tranziție între cel al țăranilor și cel al ungurenilor, dar mai apropiat de cel din urmă, și pe bufani (Sorescu-Marinković, 2012a), și ei astăzi în mare măsură asimilați lingvistic de ungureni. Ca o consecință a contactului nemijlocit permanent cu sîrba, limba oficială a statului, cu prestigiu, și a precaritatății contactelor cu româna standard, limba folosită de comunitatea românofonă din estul Serbiei e puternic influențată, mai ales la nivel lexical, de sîrbă² .

\footnotetext{
${ }^{1}$ Inițial, termenul comunități românofone s-a dovedit util și necesar în contextul cercetării de teren din Serbia, pentru a include toate grupurile de populație care vorbesc diferite variante ale limbii române, dar nu își asumă neapărat o identitate română sau și-o asumă doar parțial: românii din Vojvodina, românii/vlahii din Serbia răsăriteană, rudarii sau băieșii de pe tot cuprinsul Serbiei, noua diasporă română etc. Ulterior, odată cu scindarea comunității din Serbia răsăriteană, termenul a fost aplicat (și) acesteia.

${ }^{2}$ Pentru o prezentare mai detaliată a comunității (amplasare geografică, dimensiuni, origine, grupuri etnografice și dialec-
} 
Sentimentul de subordonare sau de independență a vernacularei față de limba română îi împarte pe membrii angajați ai comunității în două tabere opuse ${ }^{3}$, similare celor descrise în cazul disputei privind relația dintre limba galiciană și limba portugheză, din care am preluat și termenii care desemnează cele două facțiuni (vezi Sebba, 2007, p. 126-127; Salgado \& Monteagudo, 1993, p. 200-201). Tabăra „reintegraționistă” (pro-română) consideră că graiul local e o variantă a românei, adusă în Serbia prin migrație, și că diferența dintre cele două se datorează exclusiv neologismelor din româna standard, care nu au pătruns și în vernaculară (Dragić, 2007). Pentru alți membri ai comunității însă, aspectul hibrid al vernacularei, datorat împrumuturilor lexicale din sîrbă și frecventelor comutări de cod, e un argument suficient pentru a o considera o limbă distinctă, diferită de română, cu care nu e reciproc inteligibilă și pentru care, după cum ne-a declarat un membru al comunităţii, e nevoie de traducător ${ }^{4}$. Reprezentanții acestei tabere „independentiste” sau „diferențialiste” (pro-vlahă) sînt, în general, adepți ai teoriei autohtoniste și, fără să fie neapărat cei mai numeroși, sînt cu siguranță cei mai vizibili, fiind astăzi singurii reprezentați politic în Consiliul Național al Vlahilor ${ }^{5}$, ceea ce poate lăsa impresia de consens în comunitate asupra acestor chestiuni.

Între declarații extreme și atitudini moderate, ultimii ani arată că ne aflăm în faţa apariției unei conștiințe vlahe, care se opune atît identității române, cît și celei sîrbe, și al cărei produs secundar sînt acțiunile de planificare lingvistică și standardizare a limbii vlahe (Huţanu \& Sorescu-Marinković, 2015). În terminologia lui Heinz Kloss (1967), vlaha devine o limbă Ausbau. Spre deosebire de limbile Abstand (prin distanță), suficient de diferite intrinsec de alte limbi încît să fie recunoscute cu ușurință drept limbi de sine stătătoare, limbile Ausbau (prin elaborare) își creează propria identitate prin accentuarea acelor trăsături care le diferențiază de limbile cu care se înrudesc îndeaproape (în cazul nostru, româna). Kloss dă exemplul limbilor cehă și slovacă, daneză și suedeză, bulgară și macedoneană (și, am adăuga astăzi, sîrbă, croată, bosniacă şi muntenegreană), cu un grad înalt de intercomprehensiune, care prin planificare lingvistică deliberată devin și ele limbi diferite. Termenul Ausbau, avertizează Kloss (1967, p. 33), nu se poate aplica limbilor vorbite, aflate într-o etapă pre-literară, ci întregul concept presupune existența unei variante scrise și, deseori, crearea unor coduri grafice distincte.

\section{Sisteme ortografice pentru graiul românofonilor din Serbia răsăriteană - privire generală}

Deceniile de acțiuni asimilatoare ale statului sîrb au făcut ca în comunitatea românofonă din estul Serbiei să nu existe educație, și deci nici tradiție a scrierii în vernaculară. „Românii din Serbia n-au nicio cultură națională. Ei nu au nici ziare, nici școli”, observa, la sfîrșitul secolului al XIX-lea, Émile Picot (1889, p. 68), iar Vâlsan (1913, p. 341) afirma, în urma propriilor observații de teren de la începutul secolului al XX-lea, că „la vamă se distruge orice publicație românească” și că ,învățătorii care știu românește sînt strict opriți să vorbească această limbă. Copiii români care urmează la școală sînt pedepsiți dacă sînt auziți că vorbesc românește [în nota de subsol: Școală românească nu există în Serbia]”. După cîteva încercări sporadice întreprinse în anii ' 40 ai secolului trecut, abia în ultimii 20 de ani se poate vorbi de acțiuni concentrate de creare a unor sisteme de scriere pentru graiul local ${ }^{6}$.

Sistemele propuse de-a lungul timpului de membrii comunității pentru redarea acestei variante a românei se pot împărți în trei grupe principale. Prima (1945-1948) e cea a pionierilor, a primelor încercări, caracterizată printr-o atitudine neutră, neînregimentată politic. Aici se situează sistemul ortografic folosit

\footnotetext{
tale, ocupații), vezi Sorescu-Marinković (2012a, p. 17-36).

${ }^{3}$ Pentru o prezentare a unora dintre organizațiile care intră în componența acestor tabere, vezi Manovich (2014, p. 24-28).

${ }^{4}$ Manovich (2014, p. 1, p 48) descrie și ea cazul unei profesoare participante la anchetă care, la cîteva minute după ce susținuse că vlaha și româna sînt două limbi distincte, poartă o conversație telefonică cu o persoană din România și susține apoi, ca răspuns la întrebările lui Manovich, că înțelege româna, dar nu o vorbește.

${ }^{5}$ De la înființare (în 2007), Consiliul Național al Vlahilor și-a schimbat de-a lungul timpului componența și, în consecință, și atitudinea față de limbă.

${ }^{6} \mathrm{Cu}$ toate acestea, au existat cu siguranță sisteme create pentru scopuri private și înainte de această dată.
} 
de Janko Simeonović în prima publicație publicată în graiul local, „Vorba noastră” (1945-1948), și în culegerea de poezii partizane Kaнћuкатоарjа партизағаска [Kanćikatoarja partizanjaska] (1946). Cea de-a doua etapă (1950-1990) este una caracterizată de un grad mare de inconsecvență, în care au existat în paralel diferite sisteme de transcriere a acestei variante, improvizate, atît de membrii comunității, cît și de cercetători, pentru scopuri private sau pentru publicarea textelor folclorice. Biljana Sikimić (2003) a atras atenția asupra acestui fapt, afirmînd că elitele recurg la „alfabetul chirilic sau la diferite alfabete latine adaptate” (p. 87), iar textele folclorice sînt publicate cu o transcripție neadecvată (p. 86). Multe dintre aceste texte au fost publicate în revista „Razvitak”, în „Glasnik etnografskog instituta” sau „Glasnik etnografskog muzeja", de cele mai multe ori cu caractere chirilice, care nu puteau reda toate sunetele existente în graiul românofonilor (Gacović, 2016, p. 442-444; Sorescu, 2004). Nu vom discuta pe larg această etapă, deoarece textele publicate în această perioadă sînt foarte scurte, nesistematizate, de cele mai multe ori culegeri folclorice făcute de dubli insideri (Naumović, 1998), etnologi sau folcloriști amatori ori profesioniști, care provin din comunitatea românofonă din Serbia răsăriteană. Cea de-a treia etapă (ultimii 20 de ani) este una a activiștilor (Ljubiša lu Boža Kići, Paun Es Durlić, Societatea „Gergina”, Dragomir Dragić, Slavoljub Gacović), care propun sisteme ortografice încadrate într-o anume ramă ideologică și subsumate unui discurs politic (fie independentist, fie reintegraționist), mai degrabă decît unuia științific.

Înainte de a trece la analizarea sistemelor de scriere menționate mai sus, se impun cîteva observații de natură generală, care circumscriu întreaga problematică a elaborării unui sistem ortografic pentru varianta vorbită de comunitatea românofonă din estul Serbiei.

a) Principiul ortografic este, în toate sistemele propuse pînă acum, cel fonematic, considerat deseori varianta cea mai potrivită și simplă pentru redarea grafică a unui idiom nescris. La această alegere a contribuit, desigur, faptul că limba sîrbă are o ortografie „de suprafață”, care presupune înregistrarea la nivel grafic a tuturor sunetelor cu valoare funcțională și o relație fonem-grafem regulată, previzibilă şi biunivocă. Nu întîmplător, Paun Es Durlić, Dragomir Dragić sau Ljubiša lu Boža Kići fac în mai multe rînduri referire directă la avantajele ortografiei lui Vuk Karadžić, reformatorul limbii sîrbe, care, în prima jumătate a secolului al XIX-lea, a standardizat alfabetul chirilic sîrb și a impus ortografia fonematică.

b) Majoritatea sistemelor de scriere păstrează digrafia caracteristică limbii sîrbe (Lüpke, 2011, p. 316318; Ivković, 2013), care folosește două alfabete, alfabetul chirilic și alfabetul latin. Deși oficial cele două alfabete nu sînt specializate funcțional pe domenii de uz, Ivković (2013) remarcă în limba sîrbă o specializare de tip diglosic a celor două alfabete: alfabetul chirilic este cel oficial, prevăzut ca atare în Constituția Serbiei şi utilizat în inscripțiile administrative oficiale, în materialele Bisericii Ortodoxe Sîrbe, în manualele școlare, în discursurile naţionaliste și conservatoare, în timp ce alfabetul latin este preferat în presă, în publicitate, pe internet și în discursurile pro-vestice, liberale, progresive (Ivković, 2013, p. 339-341). În general, sistemele propuse pentru redarea vernacularei nu cunosc această specializare (posibil cu excepția celor propuse de Societatea „Gergina” și de Ljubiša lu Boža Kići). În plus, alegerea doar unuia dintre cele două alfabete va fi întotdeauna simptomatică pentru poziția ideologică şi atitudinea politică a propunătorilor.

c) Chiar și în cazul facțiunii reintegraționiste pro-române, convențiile ortografice sînt aproape întotdeauna cele specifice limbii sîrbe, în cazul în care fonemul aparține și structurii fonematice a sîrbei (singurul care face excepție este Slavoljub Gacović). De exemplu, ocluziva velară $/ \mathrm{k} /$ sau fricativa prepalatală $/ 3 /$ se notează în toate sistemele prin grafemele $\langle\mathrm{k}\rangle$ și $\langle\grave{\mathrm{z}}\rangle$ (respectiv $\langle\mathrm{K}\rangle$ și $\langle$ K în alfabetul chirilic), niciodată prin echivalentele specifice ortografiei române standard, $\langle\mathrm{c}\rangle$ și $\langle\mathrm{j}\rangle$. Majoritatea sistemelor (excepție fac doar Paun Es Durlić și Slavoljub Gacović) preiau, de asemenea, convențiile ortografice sîrbești privind notarea fonemelor $/ \mathrm{n} /$ și $/ K /$ (specifice vernacularei, dar inexistente în româna standard) prin digrafele sîrbești $\langle\mathrm{nj}\rangle$ și $\langle\mathrm{lj}\rangle$ (respectiv grafemele $\langle\mathrm{\omega}\rangle$ și $\langle\mathrm{b}\rangle$ în alfabetul chirilic). Ortografia limbii sîrbe se folosește și pentru redarea africatelor palatale /tc/ și /d $/$ prin $\langle\dot{c}\rangle$ și $\langle\mathrm{d}\rangle$ (respectiv $\langle\hbar\rangle>s, i<\hbar\rangle$ în alfabetul chirilic). Probleme și divergențe apar însă în cazul redării grafice a fonemelor /ə/ și / $\mathbf{i} /$, comune tuturor grupurilor dialectale, foneme inexistente în sîrbă, dar existente în 
româna standard, precum și în cazul africatei dentale /dz/ și al fricativelor /ç/ și /j/, specifice grupului bănățean, foneme inexistente în sîrbă sau în româna standard, dar existente în subdialectul bănățean al limbii române. Modul în care cei care elaborează sistemele înțeleg să rezolve aceste nepotriviri e deseori un indiciu al poziției lor ideologice.

\section{Epoca de pionierat}

Prima încercare sistematică de redare în scris a vernacularei se găsește în publicația „Vorba noastră’” , fondată în 1945 la Zaječar și editată de Janko Simeonović. Nu am reușit să obținem primul număr al acestei publicații $^{8}$, așadar nu știm dacă, măcar declarativ, exista intenția programatică de a crea și respecta anumite norme grafice sau dacă alegerea convențiilor ortografice era lăsată la latitudinea autorilor articolelor. Indiferent însă de existența sau nu a unei astfel de intenții programatice, sistemul folosit în „Vorba noastră” se caracterizează prin varietate și inconsecvență de la un număr la altul și chiar de la un articol la altul.

Sistemul propus folosește alfabetul chirilic, pe care însă îl adaptează realităților fonematice ale variantei locale, fie prin împrumutarea unor semne noi, inexistente în alfabetul chirilic, fie prin „deturnarea” valorilor fonematice ale unora dintre slove, fie prin atribuirea unor valori suplimentare unui anumit grafem. Astfel, vocala mijlocie centrală /ə/ se redă cel mai frecvent prin grafemul polivalent <a $>$ : אard [kand], gakym [fakut], uneori scris italic (ca de exemplu în unele articole din numărul 3), pentru a diferenția cele două valori ale grafemului: Gracmaмaм [blastamam]. Uneori însă, pentru redarea aceluiaşi fonem se împrumută semne grafice din ortografia românei standard: <ă >: Hoacmpă [noastră], că noamă [să poată] sau <ầ: mpâбyje [trâbuje], sezâmypâ [ljegâturâ]].

Aceeași poligrafie se întîlnește și în redarea vocalei închise centrale /ì). Cel mai frecvent se folosește

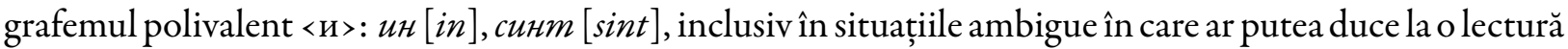
diferită: אum [kit], кинд[kind], гинд [gind]. Fonemul se mai redă uneori și prin grafemul <ì împrumutat din româna standard: 3îsussu [zîljilji ], kîm [kît], iar în cîteva situații, în grupuri consonantice construite în jurul unei sonante, grupuri specifice sîrbei, nu e redat deloc: батрна [batrna], срвјаска [srbjaska], стрмба [strmba].

În cazul fricativelor palatale $/ c ̧ / s, i / j /$, autorii recurg în general la digrafele $\langle ш j>$ : numjoape [pišjoare], mjana [šjapa], respectiv <жj>: asaжкjeм [aljažjem]. Uneori însă, mai ales în primele numere, se folosesc

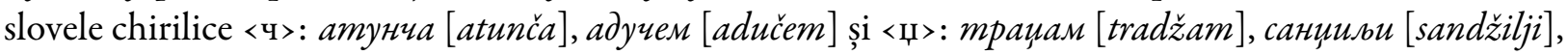
cu valoare schimbată, deoarece omologul lor fonetic este rar reperabil în vernaculară. E posibil ca deprinderile de lectură în limba sîrbă, precum și existența în grai a unor cuvinte preluate din sîrbă și deci scrise ca atare (vezi, de exemplu, nr. 21, p. 4: часовник [časovnik]), să fi dus la generalizarea digrafelor în dauna slovelor cu valoare deviată.

O situație interesantă apare în cazul africatei dentale /ck/, care în paginile analizate nu e redată în scris. Folosirea generalizată a grafemului <3> (care redă fonemul /z/), inclusiv în cazuri precum зuka [zika], acma3 [astaz], sugerează că e vorba fie de o alegere deliberată a unui grafem polivalent, fie, mai degrabă, de o trăsătură dialectală inexistentă în repertoriul fonetic al redactorului-șef sau al autorilor.

\footnotetext{
${ }^{7}$ O încercare anterioară poate fi considerată Cartea Românului din Timoc, apărută la București în 1941 sub egida Fundației Culturale Regale „Regele Mihai I”. Volumul cuprinde texte (rugăciuni, poezii patriotice, poezia Doina de Mihai Eminescu, fragmentul Țara. Poporul din România pitorească de Al. Vlahuță) pe trei coloane. În prima coloană, textele sînt redate în româna standard, în a doua sînt transcrise cu „alfabetul sîrb” (chirilic), iar în cea de-a treia cu „alfabetul croat” (latin). Volumul nu este, aşadar, o încercare de redare grafică a acestei variante a românei, ci una de echivalare a grafemelor din româna standard cu grafeme chirilice sau latine, respectînd convențiile ortografice ale limbii sîrbe. Deși volumul nu este însoțit de o prezentare a scopului sau a principiilor după care se ghidează, se poate presupune că menirea sa era să retrezească o conștiință națională presupus latentă în Timoc (prin alegerea textelor), folosind sistemele de scriere pe care destinatarii le cunoșteau. De asemenea, se pare că, pentru o scurtă perioadă de timp, săptămînalul „Nădejdea”, apărut la Vîrșeț între 1927 și 1944, a avut și o ediție cu caractere chirilice, care se distribuia în Serbia răsăriteană (cf. Gacović, 2016, p. 440).

${ }^{8}$ Numerele pe care le-am analizat (anul I, nr. 3, prima pagină; anul II, nr. 10 și nr. 21) se găsesc pe pagina web realizată de Paun Es Durlić (www.paundurlic.com/forum.vlasi.srbije).
} 
Sistemul prezentat mai sus este folosit și în culegerea de poezii partizane Kaнћuкamoapja napmuзarbacka [Kanćikatoarja partizanjaska], publicată în 1946 de redactorul-șef al ziarului „Vorba noastră”, Janko Simeonović, sub semnătura J. lu Moana Simeonović. Echivalențele ortografice sînt în general aceleași, cu mențiunea că diversitatea soluțiilor este chiar mai evidentă, fiind vorba de o carte de 28 de pagini, cu autor unic. De exemplu, în primul text al culegerii, poezia Kaндje Tuто команданm [Kand je Tito komandant], cuvîntul comandant apare de două ori scris ca în titlu (команданm [komandant]), de șase ori комӑнданm [komăndant] și o dată кoмârdarm [komândant].

După ce „Vorba noastră” și-a încetat apariția (în 1948), scrisul în grai a devenit o chestiune izolată și privată. Abia în ultimii 20 de ani se poate vorbi de noi încercări, mai mult sau mai puțin oficiale, de reprezentare grafică a vernacularei, însoțite, de obicei, de observații teoretice, în general încărcate ideologic, în funcție de atitudinile pro-românești sau pro-vlahe ale propunătorilor.

\section{Reintegraționiștii}

\subsection{Paun Es Durlić}

Cel mai cunoscut reprezentant al taberei reintegraţioniste este, probabil, Paun Es Durlić din Majdanpek, de formație etnolog, care în ultimul deceniu s-a ocupat de elaborarea unui dicționar online al graiului său (Sorescu-Marinković, 2012b). Ideile lui Paun Es Durlić sînt expuse pe site-ul său, www.paundurlic.com, care a devenit în ultimii ani spațiul de întîlnire și „cîmpul de luptă” al celor două tabere.

Sistemul ortografic propus de Paun Es Durlić în Compendiul pentru introducerea limbii rumînești în școlile primare în Serbia răsăriteană e parte a unui cadru educațional pentru predarea vernacularei în școlile primare, cu scopul de a opri asimilarea lingvistică (situația este „catastrofală”, spune autorul) și de a-i ajuta pe copii să învețe, pe lîngă graiul propriu, și româna standard, pe care membrii comunității o percep drept o limbă străină. Din acest motiv, modelul propus are două etape: într-o primă etapă (în primele patru clase), elevii ar învăța să vorbească și să scrie doar în vernaculară (în limba rumîn'ească, cum o numește autorul), în timp ce în a doua etapă (din clasa a V-a pînă în clasa a VIII-a), s-ar trece la româna standard, pe care copiii ar studia-o, parțial ca limbă străină, pe lîngă graiul propriu (Durlić, 2011, p. 3-4).

În ce privește sistemul ortografic, autorul propune folosirea ambelor alfabete, a principiului fonetic și a „metodei satelitului” (Durlić, 2011, p. 4): alfabetul chirilic rumînesc se va învăţa în clasa a II-a, după ce copiii vor fi învățat deja la școală, în clasa I, alfabetul chirilic sîrbesc, iar alfabetul latin rumîn'esc în clasa a III-a, după alfabetul latin sîrbesc, învățat în clasa a II-a. Chiar dacă nu intră în amănunte legate de aspectele tehnice ale sistemului său ortografic, deoarece „mai întîi un grup de experți trebuie să îl cerceteze temeinic și să stabilească forma sa finală” (Durlić, 2011, p. 5), Paun Es Durlić propune cîteva norme ortografice pentru redarea vernacularei. Pentru fonemele inexistente în limba sîrbă, autorul introduce, în ambele alfabete, semne preluate din alfabetul fonetic creat de dialectologii români și folosit în ALR:

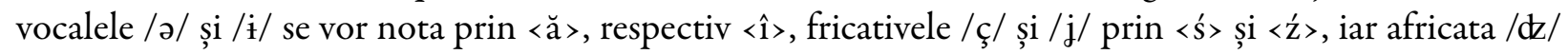
prin $\langle\underset{d}{d}>$. Preferința autorului pentru convențiile ALR se poate explica prin poziția sa ideologică privind relația dintre varianta locală și limba română: „Limba rumîn'ască poate fi considerată limbă doar în sens etno-istoric; în sens lingvistic, e vorba doar de graiuri ale subdialectelor limbii române” (Durlić, 2011, p. 1, s.a.), prin urmare sistemul folosit în lingvistica românească pentru transcrierea dialectală i se pare cel mai potrivit. De asemenea, cunoașterea sistemului ALR îi va ajuta pe elevi să citească texte dialectale culese pe teritoriul României, în special în Banat și Oltenia, ceea ce va umple „imensul gol care există din cauză că un asemenea material nu a fost cules la vreme și pe teritoriile sîrbești în care ei locuiesc" (Durlić, 2011, p. 4) și, se presupune, le va revela elevilor asemănarea dintre limba vorbită de ei și subdialectele limbii române. Nu în ultimul rînd, două dintre semne, <ă> şi <î̀, se regăsesc întocmai în ortografia românei literare, ceea ce va facilita învăţarea alfabetului românei standard.

Dorința autorului de a crea o „ortografie de tranziție” (Sebba, 2007, p. 76-79) spre româna standard se întrevede și din cîteva norme ortografice pe care autorul nu le menționează explicit în Compendiu, dar 
care apar în prezentarea ortografiei utilizate în dicționarul online ${ }^{9}$ și în cîteva fraze scrise în vernaculară în Compendiu. Astfel, pentru redarea fricativei $/ \mathrm{s} /$ și a africatei $/ \mathrm{ts} /$, autorul recurge la grafemele $\langle s,>s, i<\langle$, , specifice ortografiei românești. De asemenea, pentru redarea palatalelor $/ \mathrm{n} /$ şi $/ K /$ în alfabetul latin, autorul nu recurge la digrafele $\langle\mathrm{nj}\rangle$ și $<\mathrm{l} j\rangle$, specifice ortografiei sîrbești, ci preia semnul $<\mathrm{n}\rangle \operatorname{din}$ sistemul ALR, precum și semnul $<$ l $>$, adaptat după echivalentul IPA din tabelele ALR pentru $l$ palatalizat ${ }^{10}$, și nu pentru $l$ palatal. În același mod, în alfabetul latin autorul nu folosește grafemul $<j>$ pentru notarea semivocalei în diftongi (specific convențiilor sîrbești și păstrat în alfabetul chirilic), ci semnul <̆ $>$ (din nou, semnul IPA, nu cel folosit de dialectologii români). Autorul însuşi declară că, în crearea sistemului de transcriere a cuvintelor în dicționar, acordă o atenție deosebită tradiției ortografice românești (vezi site-ul citat), ceea ce coincide cu poziția ideologică, pro-română a autorului. Trebuie însă spus că, de-a lungul timpului, soluțiile ortografice folosite de Durlić s-au modificat simțitor: primele texte folclorice în grai publicate în anii 1980 au fost redate doar în alfabet latin sîrb (Durlić, 1982), după care autorul optează pentru alfabetul chirilic modificat (Durlić, 1987), revenind mai apoi la alfabetul latin sîrb modificat pentru a cuprinde și sunetele caracteristice graiului românofonilor (Durlić, 2001).

\subsection{Dragomir Dragić}

Dragomir Dragić din Bor, de formație inginer, este unul dintre cei mai activi membri ai comunităţii. E implicat în dezbaterile politice care înconjoară această variantă a limbii române, dar se ocupă și de chestiuni lingvistice: alături de dialectologii de la Institutul de Lingvistică și Istorie Literară „Sextil Pușcariu” din Cluj-Napoca, a participat la anchete lingvistice în Serbia răsăriteană, începînd cu anul 2004. Concepțiile sale ortografice sînt expuse în special în capitolul Pismenost kod Vlaha [Scrierea la vlahi], apărut în volumul Istraživanje zaturene istine o Vlasima [Cercetarea adevărurilor ascunse despre vlahi] ${ }^{11}$ (2007) și sînt exemplificate în culegerea de poezii populare pentru copii Pră valja Kăluculuj (Jović Kolerović et al., 2014). Culegerea e ea însăși însoțită de un prolog despre scriere, în care autorul reia unele dintre ideile sale anterioare.

În concepția autorului, singurul alfabet adecvat pentru redarea vernacularei este cel latin. Scrierea cu alfabet latin este cea originară pentru toate popoarele romanizate: toți „vlahii”-atît cei din nord (românii), cît și cei din sud (aromânii) — au folosit inițial alfabetul latin, la care au și revenit apoi, chiar și după secole de folosire a alfabetului chirilic sau a celui grec. „Vlahii din mijloc” (din Serbia răsăriteană) nu pot merge pe alt drum; orice tentativă de a impune un alt alfabet decît cel latin e strîns legată de „poluarea mentală” și de presiunile politice asupra vlahilor (Dragić, 2007, p. 28). Pentru rezolvarea interpretărilor contradictorii ale aceluiaşi fapt, implicarea lingviștilor i se pare importantă.

Deși înțelege atracția față de alfabetul chirilic, Dragić respinge sistemele propuse de alți membri ai comunității, considerînd că „ascund caracterul romanic al limbii”, că sînt „o abordare complet greșită” sau acuzîndu-i pe propunători de ipocrizie și de dorința de a-și atinge scopurile prin orice mijloace (Dragić, 2007, p. 29-30). Doar prin așezarea graiului local în context romanic și transcrierea sa cu ajutorul alfabetului latin se poate identifica asemănarea și distanța lingvistică dintre idiomuri și se poate determina „strămodelul” (srb. pramodel) cuvintelor (Jović Kolerović et al., 2014, p. 96).

Pentru a ajunge la acest „model originar”, toate textele culese în Pră valja Kăluculuj sînt redate de trei ori. Prima variantă, notată de autor prin DIAL ${ }^{12}$, este transcrierea în dialect, cea de-a doua, notată prin IPA DIAL, este transcrierea aceluiaşi text cu ajutorul semnelor IPA (în realitate, semnele ALR), iar în ultima variantă, notată LATIN COR, se elimină „alterațiile și palatalizările” și astfel se ajunge la „strămodel”, la rădăcina latinească (srb. latinski koren). De exemplu, titlul volumului este transcris Pră valja Kăluculuj (DIAL), Pră val'ea Căluțului (IPA DIAL), respectiv Pe valea Căluţului (LATIN COR).

\footnotetext{
${ }^{9}$ Vezi www.paundurlic.com/vlaski.recnik/sound.php.

${ }^{10}$ Semnul IPA /1//, folosit în sistemul ALR și preluat de Paun Es Durlić, este astăzi ieșit din uz; pentru sunetele palatalizate, IPA prevede folosirea unui $j$ suprascris (vezi www.internationalphoneticassociation.org/content/full-ipa-chart).

${ }^{11}$ Textele sînt scrise în sîrbă, așadar folosirea termenilor Vlah, Vlasi nu are conotație ideologică.

${ }^{12}$ Majusculele îi aparțin autorului sistemului.
} 
Monica Huțanu, Annemarie Sorescu-Marinković

Deși nu explică ce înțelege prin „rădăcina latinească” a cuvintelor, e clar că Dragić se referă la echivalentul din româna standard sau, cel puțin, la un echivalent redat grafic ca în româna standard. Sistemul ortografic nu poate fi privit deci decît în toate aceste trei ipostaze, simultan, deoarece pentru Dragić miza e alta: nu atît crearea unui sistem de scriere pentru varianta locală, cît demonstrarea originii române a acestei variante. Sistemul său de scriere nu este doar un instrument pentru redarea vernacularei, ci are valoare simbolică pentru recuperarea unei istorii și a unei identități.

\subsection{Slavoljub Gacović}

Un alt membru marcant al comunităţii este Slavoljub Gacović, de formaţie istoric, cu un doctorat despre istoria comunității românofone din Serbia răsăriteană susținut la Universitatea din București. În cea mai recentă lucrare a sa, Od povlašenih Srba do vlaškog jezika. O poreklu i postojbini, o seobama, o srbizaciji i asimilaciji, o maternjem jeziku i o popisima Rumuna (Vlaha) istočne Srbije [De la sîrbi vlahizați la limba vlahă. Despre origine și patrie-mamă, despre migrații, despre sîrbizare și asimilare, despre limba maternă şi despre recensămintele românilor (vlahilor) din Serbia de est] (prima parte din cel de-al cincilea volum al unei ample lucrări dedicate istoriei comunității), Gacović se ocupă, dintr-o perspectivă ideologică reintegraționistă, și de redarea în scris a variantei locale.

După ce trece în revistă cîteva dintre primele încercări empirice, nesistematice de redare în scris a variantei locale (o scrisoare din 1838, trimisă de locuitorii din Tekija prințului Miloš, un manuscris din secolul al XIX-lea al doctorului Stevan Mačaj), Gacović analizează sistemele folosite de lingviștii, etnologii şi geografii care s-au ocupat de-a lungul timpului de limba și obiceiurile comunităţii (Gustav Weigand, Tihomir Đorđević, St. Romanski, Marinko Stanojević, Jovan Đokić, Emil Petrovici) sau care au cules și publicat texte folclorice (Slobodan Zečević, Dragan Stojanjelović, Dragoslav Dević, Nikola F. Pavković, Živka Romelić) (v. Gacović, 2016, p. 429-446). Cu excepția sistemului folosit de Emil Petrovici, pe care îl acceptă în totalitate, toate celelalte modalități de redare a vernacularei i se par „neadecvate” din diverse motive: majoritatea folosesc alfabetul chirilic și convențiile ortografiei sîrbești, ceea ce duce la apariția a numeroase grafeme polifonice; sistemele propuse nu sînt potrivite pentru redarea graiurilor din Serbia de est și deci împiedică studierea acestora din perspectivă dialectologică; necunoașterea limbii de către culegători duce la greșeli în reproducerea textelor folclorice, ceea ce le poate face inutilizabile. Sistemele ortografice mai recente (cele propuse de-a lungul timpului de Paun Es Durlić și sistemul oficial al Societății „Gergina”) sînt de asemenea prezentate amănunțit și respinse: cel al lui Durlić din cauza nerespectării întocmai a „standardului APHI”, cel al Societăţii „Gergina” din cauza perspectivei ideologice independentiste din care e creat (Gacović, 2016, p. 446-460, passim).

În final, Gacović propune propriul său sistem de redare a vernacularei, un sistem în care convențiile ortografice nu mai sînt cele specifice ortografiei sîrbești, ci se bazează pe „standardul APHI” [=IPA] (Gacović, 2016, p. 460-461), prin folosirea căruia orice material dialectal va fi disponibil tuturor romaniștilor interesaţi (Gacović, 2016, p. 455). La fel ca în cazul sistemelor propuse de Durlić și Dragić, e vorba în realitate, și de această dată, de sistemul ALR folosit de dialectologii români, pe care însă Gacović îl preia și îl respectă în totalitate-cel puțin la nivel declarativ, deoarece autorul nu oferă niciun exemplu de aplicare a sistemului său ortografic. Eliminarea completă a convențiilor ortografice sîrbești și recursul la sistemul ALR reflectă și confirmă poziția ideologică pro-română a autorului.

\section{Independentiștii}

\subsection{Ljubiša lu Boža Kići}

În cîteva lucrări elaborate între 2004 și 2015 (un dicționar vlah-sîrbesc, prima traducere a evangheliilor în grai, culegeri de poezii și de povești vlahe), Ljubiša lu Boža Kići (pseudonimul lui Ljubiša Niculović), originar din satul Tanda, de lîngă Bor, propune un sistem de scriere pe care îl numește влаosuuga [vlaoljica] sau влахољица [vlaholjica] (termeni folosiți nediferențiat, creați de la vlaška ćirilica, alfabetul vlah chirilic). 
E vorba, în realitate, de mai multe variante ale sistemului ${ }^{13}$, în care autorul folosește doar alfabetul chirilic sîrbesc, la care adaugă diferite grafeme pentru a reda fonemele inexistente în sîrbă.

Pe lîngă termenul влa(x)osuna [vla(b)oljica], Ljubiša lu Boža Kići e autor și al altor creații lexicale, al căror rol e de a risipi confuziile pe care termenii Rumun, rumunski le-ar putea provoca. Astfel, în dicționarul din 2004 observă că, în limba proprie, membrii comunității nu își spun niciodată „vlahi”, ci „rumîni”, prin care înțeleg că vorbesc această variantă a limbii române, nu că sînt cetățeni ai României. Pentru a evita o astfel de confuzie, propune termenii Вларумӥн $[\text { vlarumün }]^{14}$ și вларумӥнеск [vlarumünesk] pentru a-i desemna pe „rumînii ai noștri” și limba lor (2004, p. 117), termeni la care va renunța însă în timp (același text, reluat în volumul din 2011, conține termenii Bлacu [Vlasi] și влawku [vlaški]). În prefețele volumelor din 2010b și 2011, Ljubiša lu Boža Kići introduce termenii Ромâн [român], ромâнскu [românski] (inexistenți altminteri în sîrbă, unde se folosesc Rumun și rumunski) pentru a desemna tot ce ține de români și de limba română vorbită în România.

Grija evidentă de a-i distinge pe membrii comunității de românii din România și de a distanța limba lor de cea vorbită în România e manifestă și în argumentele prin care autorul respinge alfabetul latin. Folosind alfabetul chirilic pentru scrierea limbii lor materne, vlahii vor folosi deja ceea ce știu. Alfabetul chirilic e o "garanție împotriva românizării” (lu Boža Kići, 2004, p. 118), iar vla(h)oljica va demonstra că vlahii nu trebuie să devină români ca să poată citi și scrie în limba lor maternă (lu Boža Kići, 2010b, p. iii $\left.^{15}\right)$. Deși sistemul ortografic oficial românesc, cu litere latine, e idealizat de unii și văzut ca măsură a valorilor europene, un astfel de sistem ar deveni, în concepția autorului, un mijloc de eliminare a limbii vlahe: acceptarea alfabetului românesc [românski] ar duce la acceptarea ortografiei, a gramaticii, a sintaxei românești; ar trebui aduse manuale de la București, copiii ar trebui să învețe un sistem cu totul nou de scriere; pentru modernizarea limbii s-ar folosi dicționarul românesc, care e plin de germanisme și franțuzisme, ceea ce ar duce, în timp, la izolarea întregii populații vlahe care vorbește limba vlahă autentică. Concluzia raționamentului este că, în acest caz, se va putea spune că limba vlahă nu există, există doar limba română [românski jezik] (lu Boža Kići, 2010b, p. iv-v). Cu alte cuvinte, în viziunea autorului, acceptarea alfabetului latin și a convențiilor ortografice românești ar echivala cu acceptarea statutului de români; prin crearea și folosirea unui sistem ortografic nou, dar bazat pe alfabetul chirilic, membrii comunității și-ar afirma propria identitate, diferită de cea română, oarecum apropiată de cea sîrbă, dar oricum, cu totul distinctă.

Inventivitatea dovedită în creațiile lexicale discutate mai sus apare și în propunerile ortografice ale lui Ljubiša lu Boža Kići. Neacceptînd sub nicio formă alfabetul latin românesc, autorul e nevoit să introducă semne preluate din alte ortografii sau create anume, pe care le schimbă însă de la text la text, lăsînd impresia unei permanente ,work in progress”.

Astfel, în volumele din 2004, 2006 și 2010b, fonemul /ə/ e notat prin grafemul <ë>, iar fonemul /ít prin $\langle\ddot{u}>$, semne împrumutate din alfabetul limbii germane (limbă la care autorul și face referire, alături de rusă, în scurta descriere fonetică a celor două sunete); cele două grafeme sînt preferate deoarece le sînt cunoscute acelor membri ai comunității care lucrează în străinătate ${ }^{16}$ și deci vor fi ușor de acceptat (lu Boža Kići, 2004, p. 9). În 2010a, într-o primă variantă a volumului Aлбинa: nовjewћ румйњьешћ [Albina: povješ́ rumünješć] (postată de autor pe forumul lui Paun Es Durlić), autorul propune folosirea grafemelor

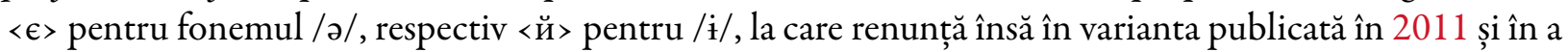

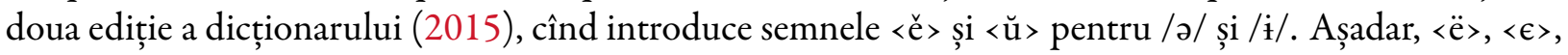

\footnotetext{
${ }^{13}$ Conform autorului, prima variantă a vla(h)oljicei datează din 1996 (lu Boža Kići, 2015, p. 16).

${ }^{14}$ Etnonimele sînt scrise cu majusculă nu doar în textul scris în limba sîrbă (conform deci normelor ortografice ale acestei limbi), ci și în textul scris în vernaculară, rezultat al influenței convențiilor sîrbești asupra ortografiei propuse.

${ }^{15}$ Paginile prefeței volumului din $2010 \mathrm{~b}$ nu sînt numerotate; numerotarea ne aparține.

${ }^{16}$ Chiar dacă sînt o comunitate relativ conservatoare și tradițională, românofonii din Serbia răsăriteană au fost extrem de mobili începînd cu anii ' 50 ai secolului trecut, aceștia reprezentînd un procent semnificativ din numărul muncitorilor iugoslavi din străinătate; unii cercetători afirmă chiar că numărul acestora era chiar de patru ori mai mare decît al sîrbilor, în anii 19601970 (Schierup \& Ålund, 1986).
} 


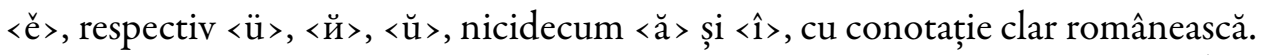

Pluralitatea soluțiilor se regăsește și în cazul perechii omorganice /ç/ - /j/. În volumele din 2004, 2006 şi 2010b, autorul propune pentru redarea lui /ç/ folosirea unui grafem creat de el însuși, prin combinarea a două caractere ale alfabetului latin. Grafemul $<\mathrm{rt}>$ (majuscula $<\mathrm{rI}>$ ) este varianta inversată, ,în oglindă” a grafemului sîrbesc $\langle\hbar>$, ceea ce face ca el să fie adecvat atît pentru rostirea ungurenilor, cît și pentru cea a țăranilor, care îl vor recunoaște pe $\langle\hbar\rangle$ și îl vor rosti /tc/, cum e specific graiului lor (lu Boža Kići, 2004, p. 9). Mai tîrziu, în cele două variante ale volumului Албинa: повјешћ румйтешћ (2010a și 2011) și în a doua ediție a dicționarului (2015), Ljubiša lu Boža Kići renunță la grafemul compus <rt > în favoarea lui $\langle$ ч $>$, și el o variantă inversată a lui $\langle\hbar\rangle$. În ce privește perechea sonoră $/ \mathrm{j} /$, în volumele din 2004 și 2006 autorul propune grafemul $\langle\mathrm{w}\rangle$, la care renunță în toate volumele următoare, introducînd grafeme preluate

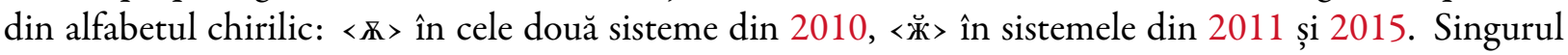
fonem în notarea căruia autorul e oarecum consecvent este africata dentală $/ \mathrm{d} z /$, redată prin digrafele $<\mathrm{dz}>$ (în 2004 și 2006) și prin <ḑ> (posibil simţit ca „mai chirilic”) în toate volumele ulterioare.

În 2015, a apărut cea de-a doua ediţie a dicționarului vlah-sîrb, în care Ljubiša lu Boža Kići propune și o variantă cu alfabet latin a sistemului său ortografic, pe care o numește laboljica. Această concesie tîrzie făcută alfabetului latin e însoțită, într-o intervenție din 2011 pe forumul lui Paun Es Durlić1 ${ }^{17}$, de afirmația că „vlahii trebuie să scrie, nu să polemizeze”. În viziunea autorului, vla(h)oljica e necesară pentru acei vlahi care încă trăiesc în sate și se ocupă cu agricultura, în timp ce laholjica se adresează acelor membri ai comunității care lucrează în străinătate și copiilor lor. Autorul păstrează grafemele $\langle\grave{e}\rangle$ și $\left\langle\mathrm{d}_{3}\right\rangle$ din ultimele variante ale sistemului său cu alfabet chirilic, dar introduce alte trei semne: grafemul $\langle\hat{i}\rangle$ pentru fonemul /ì /, grafemul <́́ $>$ pentru / j/ și semnul <ḉ pentru fonemul /ç/.

Pe lîngă lectura greoaie, inventarea unor semne pentru fonemele specifice vernacularei are și dezavantajul absenței „interlingualității” (Sebba, 2007, p. 162-163). Sebba observă că vorbitorii unei limbi știu întotdeauna cîte ceva, mai mult sau mai puțin, despre alte limbi și despre ortografiile lor și sînt capabili să folosească în diverse moduri aceste cunoștințe; evitarea obstinată a oricăror asocieri cu româna vorbită (şi scrisă) în România şi inventarea unor grafeme sau preluarea lor din alte ortografii (germană, rusă) îi exclude pe acei membri ai comunității familiarizați cu convențiile ortografice ale românei, ceea ce e un indicator clar al poziției ideologice a lui Ljubiša lu Boža Kići.

\subsection{Societatea "Gergina”}

Societatea „Gergina” pentru păstrarea tradițiilor, limbii, culturii, obiceiurilor și identității vlahilor e o organizație non-guvernamentală înfiinţată la Negotin în decembrie 2009, ale cărei obiective sînt protejarea și conservarea patrimoniului cultural și lingvistic al vlahilor din Serbia și din alte spații în care trăiesc ei azi ${ }^{18}$. În ultimii cinci ani, Societatea „Gergina” a întreprins diverse acțiuni de planificare lingvistică, materializate în elaborarea unui sistem de scriere, a unei gramatici și a unui manual de predare a limbii vlahe, precum și în introducerea orelor de limbă vlahă în cîteva școli (vezi Manovich, 2014; Huțanu \& Sorescu-Marinković, 2015).

În 2012, sistemul grafic propus de Societatea „Gergina” a fost adoptat oficial de Consiliul Naţional al Vlahilor, instituție care, în Serbia, are control absolut asupra chestiunilor ce țin de educație, cultură, massmedia în limba minorității. Printre obiectivele Consiliului Naţional al Vlahilor se numără standardizarea și codificarea scrierii în limba vlahă și introducerea limbii vlahe în uzul oficial ${ }^{19}$, de care se ocupă Comisia pentru uzul oficial al limbii și al scrierii din cadrul Consiliului. După adoptarea sa oficială, sistemul grafic a fost folosit în primul manual de predare a vlahei, Bуорба шй култура влаха [Vuorba șî kultura vlaha], apărut în 2014 sub semnătura Milenei Golubović. Titlul în vernaculară scoate în evidență poziția ideologică independentistă din care a fost elaborat manualul și, în consecință, poziția oficială a celor două asociații implicate în acțiunea de planificare lingvistică: folosirea în vernaculară a exonimului vlah pentru

\footnotetext{
${ }^{17}$ Vezi www.paundurlic.com/forum.vlasi.srbije/index.php?topic $=1121.0$.

${ }^{18}$ Vezi www.gergina.org.rs/o-nama/udruzenje.

${ }^{19}$ Vezi www.nacionalnisavetvlaha.rs/onamaciljevi.html.
} 
auto-identificare etnică (și nu a lui rumîn) are rolul de a diferenția varianta vorbită în Serbia răsăriteană de limba română și de a-i conferi astfel legitimitate. Mai mult, însăşi acțiunea de a oficializa sistemul e simbolică; așa cum observă Alexandra Jaffe (2000, p. 505-506), nu e important doar ca o ortografie nouă să existe, ci e esențial ca acea ortografie (ca instrument de creare a granițelor lingvistice) să aibă putere prescriptivă și autoritate, la fel ca ortografiile limbilor dominante.

Sistemul grafic creat de Societatea "Gergina” și oficializat de Consiliul Național al Vlahilor acceptă folosirea ambelor alfabete, atît a celui chirilic, cît și a celui latin. Alfabetul chirilic e cel folosit de vlahi de la începuturile scrisului-din 1392, de cînd ar data, conform autorilor, primul document scris cu litere chirilice, Manuscrisul de la Leud (sic) —, avînd aşadar apanajul vechimii și al tradiției. În epoca modernă însă, în care alfabetul latin în diversele sale variante e folosit la nivel global în comunicare, introducerea literelor latine li se pare autorilor o alegere logică, mai ales că mulți dintre vlahi sînt astăzi „locuitori ai Europei" ${ }^{20}$; alfabetul latin are așadar caracter internațional și este îndreptat spre modernitate.

Pentru fonemele inexistente în vernaculară, autorii introduc semne speciale, în mare parte diferite în fiecare din cele două alfabete, dar oarecum omoloage: semnului din alfabetul latin îi corespunde un echivalent chirilic, însoțit de un semn diacritic identic sau cel puțin asemănător cu cel folosit în alfabetul latin. În ambele alfabete, vocala /ə/ e redată prin grafemul <ă $>$, specific românei standard. Împrumutat din româna standard este și grafemul <î $>$ folosit pentru notarea în alfabetul latin a fonemului /ìi/, pentru care însă în alfabetul chirilic se preferă grafemul / ̆ /. Africata /dz/ se notează în alfabetul latin prin digraful $<\mathrm{dz}>$, iar în alfabetul chirilic prin echivalentul acestuia, $<A 3>$. Pentru fricativele /ç/și $/ \mathrm{j} /$, autorii propun grafemele <ś> și <́́ $>$ în alfabetul latin, respectiv <ய́ $>$ și <ж́ $>$ în alfabetul chirilic.

Sistemul oficial de scriere, varianta cu alfabet latin, e folosit în texte bilingve publicate online pe siteul „Reč naroda”, în cadrul unui proiect finanțat de Ministerul Culturii și Informării din Serbia, numit „Projekat «Ponosni Vlasi - interkulturalno Braničevo»” / „Projektu «Vlasi maruoš - Branjičeva întră kulturj»"21. E vorba de texte despre originea, limba, tradițiile vlahilor, precum și despre activitățile Consiliului Național al Vlahilor, scrise în sîrbă de Andrijana Maksimović și traduse în vlahă de Slobodan Golubović. O privire sumară asupra acestor texte scoate în evidență cîteva probleme și neconcordanțe, cauzate (și) de descrierea destul de superficială a sistemului de scriere.

Astfel, afirmația autorilor sistemului că se vor ghida după principiul „fiecărui fonem îi corespunde un grafem" ar trebui urmată de o caracterizare a structurii fonematice a variantei locale. În lipsa acesteia, cel care scrie se confruntă, în aplicarea sistemului, cu varietatea specifică rostirii, ceea ce duce la apariția unor grafii concurente, precum sî ajbe - să ajbje (la interval de cîteva rînduri), njeagră - njagră (în același text) sau njišće - nišće. O altă chestiune asupra căreia un alfabet oficial trebuie să se aplece o reprezintă criteriile prin care se delimitează cuvintele unele de altele și, în consecință, ce constituie un cuvînt (Lüpke, 2011, p. 314). Absența unor astfel de criterii explică variațiile de tipul măj batrînă - măjbatrînă, măj bun - măjbun, a dî praurmă - a dîpraurmă. În plus, e nevoie de consecvență în ce privește corespondența grafem-fonem: în cîteva situații se întîlnesc grafii influențate de convențiile ortografice specifice limbii sîrbe, cum ar fi măjnainče (cu<čc în loc de <ć >) sau prstă (în loc de prîstă, cum apare mai frecvent).

$\mathrm{O}$ altă problemă a sistemului grafic oficial ne-a fost revelată de însăși scrierea acestui articol. Grafemele <ய́〉 și <ふ́>, propuse de Societatea „Gergina” pentru redarea în alfabetul chirilic a fricativelor /ç/ și /j/, nu se regăsesc în standardul Unicode 22 și deci nici în inventarul de semne oferit de calculatoare. Pentru scrierea lor, a trebuit să recurgem la folosirea unor semne diacritice suplimentare, adăugate ulterior, ceea ce dublează timpul și efortul necesare pentru notarea unui grafem. Lüpke (2011, p. 333-334) avertizează că utilitatea și aplicabilitatea unui sistem ortografic sînt strîns legate de modul în care grafemele pot fi scrise folosind tastatura computerului, iar selectarea unor caractere nestandardizate e un semn de „miopie”, de lipsă de prevedere. Evident, există posibilitatea creării unor fonturi speciale și a propunerii lor pentru a

\footnotetext{
${ }^{20}$ Vezi www.gergina.org.rs/index.php/vlasko-pismo.

${ }^{21}$ Vezi recnaroda.co.rs/kategorije/ponosni-vlasi-vlasi-maruos. De asemenea, recent, sistemul a început să fie folosit pe site-ul Asociației „Matica Vlaha” / „Matka Vlahilor”, care are și o variantă în vlahă: matkavlahilor.org.rs/vl.

${ }^{22}$ Vezi www.unicode.org/charts/PDF/U0400.pdf.
} 
fi introduse în standardul Unicode, un proces destul de îndelungat însă, și care nu garantează acceptarea noilor caractere în acest standard.

\section{Concluzii}

În articolul de față, am abordat, dintr-o perspectivă sociolingvistică, problematica creării unei ortografii pentru un idiom nescris. Deși primele tentative sistematice de scriere în vernaculară datează din anii '40 ai secolului trecut (în special prin publicația „Vorba noastră” și prin culegerea de poezii partizane Kancíkatoarja partizanjaska), ultimii 20 de ani se remarcă prin amploarea încercărilor de redare în scris a vernacularei și prin numărul mare de sisteme propuse. Deși sistemul ortografic folosit în „Vorba noastră” le este cunoscut tuturor, niciunul dintre propunătorii de sisteme nu se revendică explicit sau implicit de la acesta. Posibil și din cauza inconsecvențelor inerente începutului, primul sistem ortografic creat pentru redarea variantei vorbite de românofonii din Serbia de est e întotdeauna menționat, dar niciodată folosit.

În plus, în ciuda oficializării sistemului de scriere și a publicării deciziei de standardizare a limbii vlahe în „Monitorul Oficial” sîrbesc în octombrie 2015, scrierea în vernaculară se găsește încă în ceea ce Rehg (2004, p. 510) numește etapa laissez-faire: chiar dacă membrii comunității știu să scrie, nu există acord general în ce privește cum ar trebui să se scrie și nici măcar ce grafeme ar trebui să se folosească. În comunitatea românofonă din Serbia răsăriteană nu există deocamdată o ortografie unică, unitară pentru că nu există o autoritate unanim acceptată. În plus, cu excepția polemicilor, divergențelor și fricțiunilor dintre propunătorii diverselor sisteme, nu există dezbatere asupra sistemelor de scriere. Scrisul în vernaculară e în acest moment un fapt rar și neobișnuit pentru membrii comunității: cărțile în vernaculară sînt puține și marginale, în general publicate în regia autorului, nu există publicații periodice, orele de limbă vlahă în școli sînt abia la început, iar înșiși propunătorii sistemelor își scriu în sîrbă textele care însoțesc, justifică, explică sistemele și poziția ideologică. Vernaculara e folosită mai ales în spațiile mai puțin regulate (Sebba, 2007, p. 44): pe internet (site-urile personale ale activiștilor, pagini de Facebook etc.), în texte private, de uz personal și, mai recent, în inscripții funerare (Huțanu \& Sorescu-Marinković, 2016).

Controversele ortografice din comunitatea românofonă din Serbia răsăriteană demonstrează importanța factorilor sociali sau politici în crearea și impunerea unui sistem grafic. Fie că servește la stabilirea similitudinii sau a diferenței față de alte coduri, alegerea unei anumite ortografii reflectă și, în același timp, creează identitate lingvistică. În cazul comunităţii cercetate, cele două tabere, reintegraţionistă și independentistă, creează ortografii care le reflectă ideologia dominantă, dar care, în acelaşi timp, sînt menite să legitimeze respectiva poziție ideologică și să-i confere autoritate.

\section{Bibliografie}

\section{A. Referințe}

Constante, C. (1929). Românii din Valea Timocului și a Moravei, în Constante \& Golopenția, 2008, vol. I, p. $215-242$.

Constante, C. \& Golopenția, A. (2008). Românii din Timoc, culegere de izvoare îngrijită de C. Constante și A. Golopenția; ediție de N. Mușat; prefață de O. Hedeșan; postfață de S. Golopenția, Editura Marineasa, Timișoara (ediția I: prefață de Dr. S. Manuilă și o introducere de E. Bucuța, vol. I-III, Imprimeria Institutului Statistic, București, s.a).

Coulmas, F. (2009). Evaluating Merit - The Evolution of Writing Reconsidered, în „Writing Systems Research”, vol. 1, nr. 1, p. 5-17, Crossref.

Dragić, D. (2007). Istraživanje zaturene istine o Vlasima, I deo, Forum za Kulturu Vlaha, Bor.

Durlić, P. (1982). Đurđevdan u Rudnoj Glavi (grada), în „Zbornik radova Muzeja rudarstva i metalurgije u Boru”, knj. 2, Bor, p. 197-199.

Durlić, P. (1987). Басме из Горғег Пореча, în „Развитак”, бр. 4-5, p. 105-118.

Durlić, P. (2001). Rokovnik za 2002. godinu sa etno-kalendarom Vlaha istočne Srbije.

Durlić, P. Es (2011). Compendiu pentru introducerea limbii rumîn'ești în școlile primare în Serbia răsăriteană, [online].

Eira, C. (1998). Authority and Discourse: Towards a Model for Orthography Selection, în „Written Language \& Literacy”, vol. 1, nr. 2, p. 171-224, Crossref.

Florea, S. (2015). Avataruri ale identității - discurs public și parcurs intim. Studiu de caz - românofonii din Serbia de răsărit (teză de doctorat susținută în 2015 la SNSPA București, coordonator Vintilă Mihăilescu). 
Gacović, S. (2016). Od povlašenih Srba do vlaškog jezika. O poreklu i postojbini, o seobama, o srbizaciji i asimilaciji, o maternjem jeziku i o popisima Rumuna (Vlaha) istočne Srbije, Fabula Nostra, Beograd, Književno-izdavačko društvo Leksika, Negotin, 2016.

Golubović, М. (2014). Вуорба шй култура Влаха: Уибеник из предмета влашки говор са елементима националне културе за први разред основне школе, Zavod za udžbenike, Beograd, Nacionalni Savet Vlaha, Petrovac na Mlavi.

Huțanu, M. \& Sorescu-Marinković, A. (2015). Graiul vlah în școlile din Serbia răsăriteană: provocări și perspective, în „Philologica Jassyensia”, vol XI, nr. 2, p. 201-211.

Huțanu, M. \& Sorescu-Marinković, A. (2016). Novi nadgrobni natpisi na vlaškom u istočnoj Srbiji, în „Folkloristika”, 1/2, p. 2742, [online].

Irvine, J.T. \& Gal, S. (2000). Language Ideology and Linguistic Differentiation, în Kroskrity, P.V. (ed.), Regimes of Language: Ideologies, Polities, and Identities, School of American Research Press, Santa Fe, p. 35-84, [online].

Ivković, D. (2013). Pragmatics Meets Ideology. Digraphia and Non-Standard Orthographic Practices in Serbian Online News Forums, în „Journal of Language and Politics”, vol. 12, nr. 3, p. 335-356, Crossref.

Jaffe, A. (2000). Introduction: Non-Standard Orthography and Non-Standard Speech, în „Journal of Sociolinguistics”, vol. 4, nr. 4, p. 497-513, Crossref.

Jović Kolerović, S., Dragić, D., Paunjelović, F., Stojanjelović, D. \& Mitrović Mitra, V. (2014). Pră valja Kăluculuj / Pră valea Căluțului / Pe valea Căluțului: Dečje vlaške pesme, Štamparija Stojadinović, Petrovac na Mlavi.

Kloss, H. (1967). 'Abstand languages' and 'Ausbau languages', în „Anthropological Linguistics”, vol. 9, nr. 7, p. 29-41, [online].

lu Boža Kići, Lj. (2004). Влашко-српски речник. Вларумӥнеск-србјеск ворбарjу, Grafomed, Bor.

lu Boža Kići, Lj. (2006). Јевангеља сфӥнтё, Grafomed, Bor.

lu Boža Kići, Lj. (2010a). Албина: повјешћ румйжешћ = влашке приповетке, [fragment disponibil online].

lu Boža Kići, Lj. (2010b). Влашке песме, Grafomed, Bor.

lu Boža Kići, Lj. (2011). Албина: повјешћ румйњешћ = влашке приповетке (допуњено издање), Nacionalni Savet Vlaha, Negotin, Štamparija Stojadinović, Petrovac.

lu Boža Kići, Lj. (2015). Влашко-српски речник. Вларумӥъеск-србјеск ворбарју (2. допуњено изА.), Тегсіjа, Bor.

Lüpke, F. (2011). Orthography Development, in Austin, P.K. \& Sallabank, J. (eds), The Cambridge Handbook of Endangered Languages, Cambridge University Press, p. 312-336, [online].

Manovich, D. (2014). Folk Linguistics and Politicized Language: the Introduction of Minority Language Education for the Vlachs in Serbia (submitted to Central European University Nationalism Studies Program in partial fulfilment of the requirements for the degree of Master of Arts), Budapest, [online].

Meteș, Ș. (1971). Emigrări românești din Transilvania în secolele XIII-XX. (Cercetări de demografie istorică), Editura Științifică, București.

Naumović, S. (1998). Romanticists or Double Insiders? An Essay on the Origins of Ideologised Discourses in Balkan Ethnology, în „Ethnologia Balkanica”, vol. 2, p. 101-120, [online].

Pătruț, I. (1942). Folklor de la Românii din Sîrbia, în „Anuarul arhivei de folklor”, VI, p. 329-384.

Petrovici, E. (1942). Note de folklor de la Romînii din Valea Mlavei (Sîrbia), în „Anuarul arhivei de folklor”, VI, p. 43-75.

Picot, É. (1889). Românii din Timoc, traducere din limba franceză de C. Constante, în Constante \& Golopenţia, 2008, vol. I, p. 67-70.

Popovici, A. (1919). Memoriul românilor din Serbia, în Constante \& Golopenția, 2008, vol. II, p. 108-122.

Priestly, T.M.S. (1992). Problems in the Creation of an Orthography: Functional Load, Interference, and Political Preferences, în „Slavic and East European Journal”, vol. 36, nr. 3, p. 302-316, Crossref.

Rehg, K. L. (2004). Linguists, Literacy, and the Law of Unintended Consequences, în „Oceanic Linguistics”, vol. 43, nr. 2, p. 498518, [online].

Schieffelin, B.B. \& Doucet, R.C. (1994). The "Real" Haitian Creole: Ideology, Metalinguistics, and Orthographic Choice, în „American Ethnologist”, vol. 21, nr. 1, p. 176-200, Crossref.

Salgado, B. F. \& Monteagudo, H. (1993). The Standardization of Galician: The State of the Art, în „Portuguese Studies”, vol. 9, p. 200-213, [online].

Sallabank, J. (2002). Writing in an Unwritten Language: The Case of Guernsey French, în „Reading Working Papers in Linguistics", vol. 6, p. 217-244, [online].

Schierup, C.-U. \& Ålund, A. (1986). Will They Still Be Dancing? Integration and Ethnic Transformation among Yugoslav Immigrants in Scandinavia, University of Umeå, [online].

Sebba, M. (2007). Spelling and Society. The Culture and Politics of Orthography around the World, Cambridge University Press.

Sebba, M. (2015). Iconisation, Attribution and Branding in Orthography, în „Written Language \& Literacy”, vol. 18, nr. 2, p. 208-227, Crossref.

Sikimić, В. (2003). Полевьц исследования „влахов” в северо-восточной Сербии, în Соволев, А.Н. \& Русаков, А.Ю. (eds), Актуальные вопросы балканского языкознания, Наука, Санкт-Петербург, р. 85-96.

Sikimić, B. (2014). Romanians in Serbian Banat: Dynamic Epistemology, în Kamusella, T. \& Nomachi, M. (eds), The Multilingual Society Vojvodina. Intersecting Borders, Cultures and Identities, Slavic Research Center, Hokkaido University, Sapporo, p. 51-73, [online]. 
Sorescu, A. (2004). The Vlach Folk Literature - An Identity Document that Has not Been Printed Yet, în Kruжкевност на језицима манина у Подунављу, Београд: Институт за книжевност и уметност, Институт за књижевност, БеограА, p. $185-193$.

Sorescu-Marinković, A. (2007). Comunități românofone din Serbia. Identitate lingvistică sau ceva mai mult?, în Botoșineanu, L. et al. (eds), Români majoritari / Români minoritari: interferențe și coabitări lingvistice, literare și etnologice, Editura Alfa, Iași, p. 863-875.

Sorescu-Marinković, A. (2012a). Românii din Timoc astăzi. Ființe mitologice, Editura Argonaut, Cluj-Napoca.

Sorescu-Marinković, A. (2012b). Vorbarĭ Ruminnesk: The Vlach on line Dictionary, în „Philologica Jassyensia”, vol. VIII, nr. 1, p. 47-60.

Unseth, P. (2005). Sociolinguistic Parallels between Choosing Scripts and Languages, în „Written Language \& Literacy”, vol. 8, nr. 1, p. 19-42, Crossref.

Unseth, P. (2008). The Sociolinguistics of Script Choice: An Introduction, în „International Journal of the Sociology of Language”, vol. 192, p. 1-4, Crossref.

Vâlsan, G. (1913). Românii din Bulgaria și Serbia, în Constante \& Golopenția, 2008, vol. I, p. 328-344.

Weigand, G. (1900). Dialectele românești ale Valabiei mici, ale Serbiei și ale Bulgariei, în Constante \& Golopenția, 2008, vol. I, p. $71-87$.

\section{B. Site-uri web}

www.gergina.org.rs

www.internationalphoneticassociation.org

matkavlahilor.org.rs/vl

www.nacionalnisavetvlaha.rs

www.paundurlic.com

www.recnaroda.co.rs/kategorije/ponosni-vlasi-vlasi-maruos

www.unicode.org 